\title{
Delineation and Characterization of Purvi Nayyar River Watershed in Mid- Himalayan Region of India Using Remote Sensing and GIS Techniques
}

\author{
Ritu Nagdev ${ }^{1 *}$, S.K. Mahapatra ${ }^{1}$, R.P. $\operatorname{Yadav}^{1}$ and S.K. Singh ${ }^{2}$ \\ ${ }^{1}$ ICAR-National Bureau of Soil Survey and Land Use Planning, Regional Centre, \\ IARI Campus, New Delhi-110012, India \\ ${ }^{2}$ ICAR-National Bureau of Soil Survey and Land Use Planning, Amravati Road, \\ Nagpur-440033, Maharashtra, India \\ *Corresponding author
}

\section{A B S T R A C T}

K e y w o r d s
Warm humid
Himalayas,
Pauri Garhwal,
Watershed,
Physiographic land
unit, Entisols,
Inceptisols and
Land degradation.
Article Info
Accepted:
21 August 2017
Available Online:
10 September 2017

Keywords

Warm humid Himalayas, Pauri Garhwal, Physiographic land unit, Entisols, Inceptisols and Land degradation.

Article Info

21 August 2017

10 September 2017
Remote sensing and GIS techniques were used to delineate and characterize the Purvi Nayyar river watershed in Pauri Garhwal district of Uttarakhand, India pertaining to warm humid Himalayan ecosystem. Based on image characteristics and ground truth studies, four major physiographies viz., hill/ridge tops, side/reposed slopes, valleys and escarpments were delineated. They were further subdivided into ten physiographic units based on slopes and integrated with land use systems to delineate physiographic land units (PLU). Ten soils were identified occurring on different PLUs. Major soils occur on hill/ridge tops and side/reposed slopes and are very shallow to moderately shallow in depth, excessively drained, gravelly loamy sand and coarse sandy loam in texture and single grain to massive in structure. They have only A-C horizons underlain by indurated bed rock at 11 to $81 \mathrm{~cm}$ depth and belong to Entisols. Soils of valleys are deep to very deep, well drained, sandy loam to sandy clay loam in texture, medium, weak and moderate subangular blocky in structure having A-B-C horizons and belong to Inceptisols. Soils are acidic in nature with low to medium cation exchange capapcity and very low to low water holding capacity. Since, the watershed area is highly prone to various kinds of degradation, suitable soil and water conservation measures have been suggested to maintain soil health and integrated development of the area.

\section{Introduction}

Watershed is an area of land and water bounded by a drainage divide within which the surface runoff accumulates and flows out of the watershed through a single outlet into a large river or lake. The watershed programme is primarily a land based programme, which is increasingly being focused on water, with its main objective being to enhance agricultural productivity through increased moisture conservation and protective irrigation for socio-economic development of rural people. Integrated watershed management aims to alleviate poverty and improve living standards by improving sustainable livelihood opportunities for households and communities whose needs are met from a watershed's natural resources. It also improves the conservation and protection of forest areas that are important for preserving biodiversity and protecting water resources for sustainable 
economic productivity. The development of hill and mountain areas and protection of their ecology have become matters of national concern in recent years. These areas differ from the plains in topography, elevation, physiographic features, diversity of habitats for flora and fauna, ethnic diversity, land use systems and socio-economic conditions. In accessibility, fragility, marginality, heterogeneity, natural instability and human adaptation mechanism are the key factors to be focused for sustainable agricultural development in such areas. Thus, management of natural resources, specially soils has become imminent in this region. Soils are indispensable natural resources for any developmental planning in hilly region (Mahapatra et al., 2005) but their indiscriminate use and over exploitation have adverse impact on the ecology (Blum, 1997 and Gorai et al., 2013). Application of remote sensing and GIS techniques were found to be very useful in soil resource inventory (Dwivedi, 2001; Reddy et al., 2008; Srivastava and Saxena, 2004). Mishra and Ghosh (1995) and Pai et al., (2007) established soil-landform relationship and found it to be useful criteria for site specific management of soils. Some researchers have worked on some specific sites of hilly region (Kumar and Sharma 1987; Divakar et al., 1989; Rawat et al., 1994; Singh and Bhatnagar 1997; Ghosh and Singh 2002) but information on the soils of Garhwal region is still inadequate.

Agricultural production in the Garhwal region of warm humid Himalayas showed declining trend in the recent past. Soil losses were estimated to be high due to significant land use changes like construction of dams and other non-agricultural activities. Potential agricultural lands were lost along the river terraces. This caused stress on the available land for agricultural production in the region to meet the food demands. Therefore, a concern for watershed management through the soil resource inventory and spatial data generation was felt as the need for systematic assessment and agricultural planning.

Therefore, the present study was undertaken with an objective to delineate and characterize the Purvi Nayyar river watershed in mid Himalayan region using remote sensing and GIS techniques for the agricultural and overall development of the area (Fig. 1).

\section{Materials and Methods}

\section{Study area}

The study area belongs to Purvi Nayyar river watershed of Pauri Garhwal district of Uttarakhand state in India, spread over $29^{\circ} 53^{\prime} 45^{\prime \prime}$ to $29^{\circ} 58^{\prime} 50^{\prime \prime}$ ' $\mathrm{N}$ latitudes and $78^{\circ} 54^{\prime} 48^{\prime}$ ' to $78^{\circ} 59^{\prime} 47^{\prime}$ ' $\mathrm{E}$ longitudes covering7,480 ha area. The area falls under warm humid lesser Himalayas, Agroecological sub region (AESR) 14.2 and is marked with rugged terrain having steep and high ridges. The elevation ranges from 1100to $2697 \mathrm{~m}$ above msl. The area is drained through Purvi Nayyar River and several drainage channels including khads. This river is merged into the main Nayyar River which ultimately merges into the river Ganga.

A 3 tier approach was adopted to assess the soil resources i.e., image interpretation, ground truth verification and soil resource characterization.

\section{Image interpretation and ground truth verification}

The soil resource inventory was made by interpreting the Indian Remote Sensing satellite (IRS-ID LISS III) data FCC encoded imageries of bands 2, 3 and 4 and Survey of India toposheet $(53 \mathrm{~K} / 13)$ were interpreted to delineate the landform units. Geomorphic 
features were interpreted on the basis of key image elements such as shape, tone or colour, pattern, shadow, association and texture (Sahu et al., 2016). Landforms identified were further subdivided into physiographic units based on their elemental characteristics and slope functions of landforms. Physiographic land unit (PLU) map was generated by incorporating physiography with land use/land cover and corrected through ground truth verification. Different land use systems and parent materials were noted while traversing the area and during the ground truth observations.

\section{Soil resource inventory and characterization}

Soil survey was conducted using PLU map. Soils of different physiographic units and land use systems were studied in the field to determine morphological properties by digging mini pits and master pedons (Sehgal et al., 1987; Bhattacharya et al., 2009). Soil physiography relationship was established. Soil samples of each horizon of representative pedons were collected and characterised for important properties (Black 1965; Jackson 1966; Sharma et al., 1987). Different soil series identified in different physiographic units were classified as per the soil taxonomy (Soil Survey Staff 2014).Soil and thematic maps were generated using GIS technique. Based on physiography, type of soils and their constraints and potentials, appropriate management practices and land use plans have been suggested for higher productivity.

\section{Results and Discussion}

\section{Delineation of physiographic land units (PLU)}

Image interpretation resulted into delineation of four major physiographies viz., hill/ridge tops, side/reposed slopes, valleys and very steeply sloping escarpments. Based on the image elements and slope functions they were further divided into ten physiographic units viz., steeply sloping hill/ridge tops, moderately steeply sloping hill/ridge tops, moderately sloping hill/ridge tops, very steeply sloping side/reposed slopes, steeply sloping side/reposed slopes, moderately steeply sloping side/reposed slopes, moderately sloping side/reposed slopes, gently sloping narrow valleys, very gently sloping broad valleys and very steeply sloping escarpments. Different land use systems identified are barren and scrub land, thin forest and bushes, dense forest, medium forest, grazing land, cultivated land, cultivated land along with plantations, barren and denuded land, respectively. The physiographic land unit map generated by incorporating physiographic units and land use (Table 1) has been depicted in figure 2 . The map contained ten PLUs and was used for soil resource inventory of the watershed area.

\section{Soils and their properties}

On the basis of ground truth study and soil resource characterization ten types of soil (P1 to P10) have been identified viz., Phoolchatti, Umrda, Jollu, Mundai, Kainur, Maun, Bhandeli, Sigadi, Gularjhala and Chourikhal, respectively. They have been mapped as phases of soil series (based on surface texture, slope and erosion) containing 18 soil mapping units. The soil map has been depicted in figure 3 and their properties have been described in table 2. Phoolchatti (P1) soils are very shallow in depth with only a horizon having abrupt smooth boundary, yellowish brown in colour, loamy sand in texture with strong coarse gravels, single grain in structure, underlain by indurated bedrock at $11 \mathrm{~cm}$ depth and developed on mica schist. Umrda (P2) soils are shallow in depth with A$\mathrm{C}$ horizons having clear and abrupt smooth 
boundaries, yellowish brown in colour, sandy loam in texture with strong coarse gravels, massive and single grain in structure underlain by indurated bedrock at $27 \mathrm{~cm}$ depth and developed on sandstone. Jollu (P3) soils are moderately shallow in depth with AAC-C horizons having clear, gradual and abrupt smooth boundaries underlain by indurated bedrock at $73 \mathrm{~cm}$ depth and developed on mica schist. They are dark yellowish brown to yellowish brown in colour, loamy sand in texture and single grain in structure. Mundai $(\mathrm{P} 4)$ soils are moderately deep in depth with A-C horizons having gradual, clear and abrupt smooth boundaries underlain by indurated bedrock at $80 \mathrm{~cm}$ depth and developed on mica schist. They are grayish brown to dark grayish brown in colour, loamy sand in texture with strong gravels throughout the profile increasing downwards and single grain in structure. Kainur (P5) soils are very shallow in depth with only a horizon having abrupt smooth boundary, grayish brown in colour, loamy sand in texture with strong coarse gravels, single grain in structure, underlain by indurated bedrock at $22 \mathrm{~cm}$ depth and developed on mica schist. Maun (P6) soils are shallow in depth with A-C horizons having clear and abrupt smooth boundaries, brown in colour, sandy loam in texture with strong coarse gravels, disturbed and single grain in structure underlain by indurated bedrock at 32 $\mathrm{cm}$ depth and developed on sandstone. Bhandeli (P7) soils are moderately deep in depth with A-C horizons having clear, gradual and abrupt smooth boundaries underlain by indurated bedrock at $81 \mathrm{~cm}$ depth and developed on mica schist. They are dark grayish brown to grayish brown in colour, loamy sand in texture and single grain in structure. Sigadi (P8) soils are deep in depth with A-C horizons having clear, gradual and abrupt smooth boundaries underlain by indurated bedrock at $105 \mathrm{~cm}$ depth and developed on sandstone. They are dark yellowish brown to yellowish brown in colour, sandy loam in texture, disturbed and single grain in structure. Gularjhala (P9) soils are deep in depth with A-B-C horizons having clear, gradual and abrupt smooth boundaries underlain by unconsolidated bedrock at 115 $\mathrm{cm}$ depth and developed on colluvium/alluvium. They are dark yellowish brown to yellowish brown in colour, sandy loam in texture, disturbed and medium, weak, sub angular blocky in structure. Chourikhal (P10) soils are very deep in depth with A-B horizons having gradual and clear smooth boundaries developed on alluvium/colluvium. They are brown to dark yellowish brown in colour, sandy clay loam in texture and disturbed, fine and medium, weak and moderate sub angular blocky in structure. Thus, the study revealed that the physiography and parent materials played an important role in development and determination of types of soils.

The soils are acidic ( $\mathrm{pH}$ varies from 5.3 to 6.2) in reaction (Fig. 4) with major soils belonging to slight $(\mathrm{pH} \quad 6.1 \quad-\quad 6.5)$ to moderately acidic ( $\mathrm{pH} 5.6-6.0)$ with patches of strongly acidic ( $\mathrm{pH} 5.1-5.5)$ soils. The acidic nature of the soils is due to leaching of bases because of sloppy landscape and high intensity rainfall prevailing in the area. The electrical conductivity (Fig. 5) is very low to low (EC less than $0.50 \mathrm{dSm}^{-1}$ ) due to removal of soluble salts from the soil profiles at higher elevations as mentioned in soil reaction. The distribution of clay particles in the soils of the study area (Fig. 6) revealed that it is low to very low in hill/ridge tops and side/reposed slopes whereas, it is moderate to comparatively high in valleys due to removal of finer soil particles from the higher elevations along with runoff water during heavy rains and its deposition in lower areas. The cation exchange capacity (CEC) of the soils has been depicted in figure 7 which revealed that CEC is very low to low with 
medium value in patches. It is due to the reason that the soils are mainly coarse texture (loamy sand to coarse sandy loam) except Chourikhal soils which is sandy clay loam in texture. The values of CEC are controlled by organic matter, clay content and its constituent clay minerals (Sawhney et al., 1996; Gorai et al., 2013).

\section{Taxonomy of soils}

Soils of the watershed has been classified as per USDA soil taxonomy and presented in table 3. The temperature and moisture regimes of the study area are thermic and udic, respectively. The mineralogy of all the soils aremixed type. Phoolchatti soils are very shallow, excessively drained, loamy sand in texture with coarse gravels throughout the profile and have only a horizon underlain by indurated bedrock at $11 \mathrm{~cm}$ depth. Hence, they belong to Entisols having sandy skeletal family textural class (as the texture is loamy sand with more than $35 \%$ coarse gravels) and are classified as very shallow, mixed, thermic, sandy skeletal Lithic Udorthents. Umrdasoils are shallow, excessively drained, sandy loam in texture with coarse gravels throughout the profile and have A-C horizons underlain by indurated bedrock at $27 \mathrm{~cm}$ depth. Hence, they belong to Entisols having loamy skeletal family textural class (as the texture is sandy loam with more than $35 \%$ coarse gravels) and are classified as shallow, mixed, thermic, loamy skeletal Lithic Udorthents. Jollu soils are moderately shallow, excessively drained, loamy sand in texture and have A-AC-C horizons underlain by indurated bedrock at 73 $\mathrm{cm}$ depth. Hence, they belong to Entisols having sandy family textural class and are classified as moderately shallow, mixed, thermic, Typic Udipssaments. Mundai soils are moderately deep, excessively drained, loamy sand in texture with coarse gravels throughout the profile and have A-C horizons underlain by indurated bedrock at $80 \mathrm{~cm}$ depth. Hence, they belong to Entisols having sandy skeletal family textural class and are classified as moderately deep, mixed, thermic, sandy skeletal Typic Udorthents. Kainursoils are very shallow, excessively drained, loamy sand in texture with coarse gravels throughout the profile and have only a horizon underlain by indurated bedrock at $22 \mathrm{~cm}$ depth. Hence, they belong to Entisols having sandy skeletal family textural class and are classified as very shallow, mixed, thermic, sandy skeletal Lithic Udorthents. Maun soils are shallow, excessively drained, sandy loam in texture with coarse gravels throughout the profile and have A-C horizons underlain by indurated bedrock at $32 \mathrm{~cm}$ depth. Hence, they belong to Entisols having loamy skeletal family textural class and are classified as shallow, mixed, thermic, loamy skeletal Lithic Udorthents. Bhandeli soils are moderately deep, excessively drained, loamy sand in texture and have A-C horizons underlain by indurated bedrock at $81 \mathrm{~cm}$ depth. Hence, they belong to Entisols having sandy family textural class and are classified as moderately deep, mixed, thermic, Typic Udipssaments. Sigadi soils are deep, somewhat excessively drained, sandyloam in texture and have A-C horizons underlain by indurated bedrock at $105 \mathrm{~cm}$ depth. Hence, they belong to Entisols having coarse loamy family textural class and are classified as deep, mixed, thermic, coarse loamy, Typic Udorthents. Gularjhala soils are deep, sandy loam in texture, medium, weak subangular blocky in structure and have A-B$\mathrm{C}$ horizons underlain by unconsolidated bed rock at $115 \mathrm{~cm}$ depth. These soils are comparatively well developed having cambic diagnostic $(\mathrm{Bw})$ horizon and hence belong to Inceptisols having base saturation less than $60 \%$ and no free carbonates throughout the profile and hence are classified as deep, mixed, thermic, coarse loamy, Typic Dystrudepts. Chourikhal soils are very deep, sandy clay loam in texture, fine to medium, weak and moderate, sub angular blocky in structure and have A-B horizons. 


\begin{tabular}{|c|c|c|c|}
\hline \multicolumn{4}{|c|}{ Table.1 Interpretation of remote sensing data } \\
\hline S. No. & Image Characteristics & Physiography & Land Use \\
\hline 1 & $\begin{array}{l}\text { Blackish tone with dark } \\
\text { brown to reddish patches and } \\
\text { rough texture }\end{array}$ & $\begin{array}{l}\text { Steeply sloping } \\
\text { hill/ridge tops }\end{array}$ & $\begin{array}{l}\text { Mostly barren and } \\
\text { scrub land }\end{array}$ \\
\hline 2 & $\begin{array}{l}\text { Dark brown tone with reddish } \\
\text { patch and coarse texture }\end{array}$ & $\begin{array}{l}\text { Moderately steeply } \\
\text { sloping hill/ridge tops }\end{array}$ & $\begin{array}{l}\text { Thin forest and } \\
\text { bushes }\end{array}$ \\
\hline 3 & $\begin{array}{l}\text { Bright red tone, smooth } \\
\text { texture with dense granular } \\
\text { patches }\end{array}$ & $\begin{array}{l}\text { Moderately sloping } \\
\text { hill/ridge tops }\end{array}$ & Dense forest \\
\hline 4 & $\begin{array}{l}\text { Light bluish tone with light } \\
\text { brownish patches, medium } \\
\text { coarse texture }\end{array}$ & $\begin{array}{l}\text { Very steeply sloping } \\
\text { side/reposed slopes }\end{array}$ & $\begin{array}{l}\text { Barren and scrub } \\
\text { land }\end{array}$ \\
\hline 5 & $\begin{array}{l}\text { Bright bluish tone, medium } \\
\text { coarse texture }\end{array}$ & $\begin{array}{l}\text { Steeply sloping } \\
\text { side/reposed slopes }\end{array}$ & Grazing land \\
\hline 6 & $\begin{array}{l}\text { Bluish tone, coarse texture } \\
\text { and scattered grains }\end{array}$ & $\begin{array}{l}\text { Moderately steeply } \\
\text { sloping side/ reposed } \\
\text { slopes }\end{array}$ & $\begin{array}{l}\text { Mostly cultivated } \\
\text { land }\end{array}$ \\
\hline 7 & $\begin{array}{l}\text { Whitish tone, smooth texture } \\
\text { and fine scattered grains }\end{array}$ & $\begin{array}{l}\text { Moderately sloping } \\
\text { side/ reposed slopes }\end{array}$ & Medium forest \\
\hline 8 & $\begin{array}{l}\text { Light pinkish and brownish } \\
\text { tone, scattered grains and } \\
\text { mottled texture }\end{array}$ & $\begin{array}{l}\text { Gently sloping narrow } \\
\text { valleys }\end{array}$ & $\begin{array}{l}\text { Mostly cultivated } \\
\text { land }\end{array}$ \\
\hline 9 & $\begin{array}{l}\text { Light pinkish and whitish } \\
\text { tone with smooth and } \\
\text { diffused texture }\end{array}$ & $\begin{array}{l}\text { Very gently sloping } \\
\text { broad valleys }\end{array}$ & $\begin{array}{ll}\text { Cultivated land } \\
\text { along with fruit } \\
\text { plantations }\end{array}$ \\
\hline 10 & $\begin{array}{l}\text { Dark blackish brown tone, } \\
\text { coarse texture and irregularly } \\
\text { scattered grains }\end{array}$ & $\begin{array}{l}\text { Very steeply sloping } \\
\text { escarpments }\end{array}$ & Barren and denuded \\
\hline
\end{tabular}




\begin{tabular}{|c|c|c|c|c|c|c|}
\hline \multicolumn{7}{|c|}{ Table. 2 Characteristics of the soils } \\
\hline Soil series & Horizon & $\begin{array}{l}\text { Depth } \\
\text { (cm) }\end{array}$ & Boundary & Colour & Texture & Structure* \\
\hline \multirow{2}{*}{$\begin{array}{l}\text { Phoolchatti } \\
\text { (PI) }\end{array}$} & $\mathrm{A}$ & $0-11$ & Abrupt, smooth & Yellowish brown & Gravelly loamy sand & Single grain \\
\hline & $\mathrm{R}$ & $11+$ & Indurated bedrock & - & - & - \\
\hline \multirow{3}{*}{$\begin{array}{l}\text { Umrda } \\
\text { (P2) }\end{array}$} & $\mathrm{A}$ & $0-15$ & Clear, smooth & Yellowish brown & Gravelly sandy loam & Massive \\
\hline & $\mathrm{C}$ & $15-27$ & Abrupt, smooth & Yellowish brown & Gravelly sandy loam & Single grain \\
\hline & $\mathrm{R}$ & $27+$ & $\begin{array}{l}\text { Indurated bedrock } \\
\text { rock }\end{array}$ & - & - & - \\
\hline \multirow{5}{*}{$\begin{array}{l}\text { Jollu } \\
\text { (P3) }\end{array}$} & A1 & $0-16$ & Clear, smooth & Dark yellowish brown & Loamy sand & Single grain \\
\hline & $\mathrm{A} 2$ & $16-35$ & Gradual, smooth & Yellowish brown & Loamy sand & Single grain \\
\hline & $\mathrm{AC}$ & $35-62$ & Clear, smooth & Yellowish brown & Loamy sand & Single grain \\
\hline & $\mathrm{C}$ & $62-73$ & Abrupt, smooth & Yellowish brown & Loamy sand & Single grain \\
\hline & $\mathrm{R}$ & $73+$ & Indurated bedrock & - & - & - \\
\hline \multirow{4}{*}{$\begin{array}{l}\text { Mundai } \\
\text { (P4) }\end{array}$} & A1 & $0-15$ & Gradual, smooth & Grayish brown & Gravelly loamy sand & Single grain \\
\hline & $\mathrm{A} 2$ & $15-36$ & Clear, smooth & Grayish brown & Gravelly loamy sand & Single grain \\
\hline & $\mathrm{C}$ & $36-80$ & Abrupt, smooth & Dark grayish brown & Gravelly loamy sand & Single grain \\
\hline & $\mathrm{R}$ & $80+$ & Indurated bedrock & - & - & - \\
\hline \multirow{2}{*}{$\begin{array}{l}\text { Kainur } \\
\text { (P5) }\end{array}$} & $\mathrm{A}$ & $0-22$ & Abrupt, smooth & Grayish brown & Gravelly loamy sand & Single grain \\
\hline & $\mathrm{R}$ & $22^{+}$ & Indurated bedrock & - & - & - \\
\hline \multirow{3}{*}{$\begin{array}{l}\text { Maun } \\
\text { (P6) }\end{array}$} & Ap & $0-15$ & Clear, smooth & Brown & Gravelly sandy loam & Disturbed \\
\hline & $\mathrm{C}$ & $15-32$ & Abrupt, smooth & Brown & Gravelly sandy loam & Single grain \\
\hline & $\mathrm{R}$ & $32+$ & Indurated bedrock & - & - & - \\
\hline \multirow{5}{*}{$\begin{array}{l}\text { Bhandeli } \\
\text { (P7) }\end{array}$} & A1 & $0-14$ & Clear, smooth & Dark grayish brown & Sandy loam & Massive \\
\hline & $\mathrm{A} 2$ & $14-36$ & Gradual, smooth & Grayish brown & Loamy sand & Single grain \\
\hline & A3 & $36-55$ & Gradual, smooth & Grayish brown & Loamy sand & Single grain \\
\hline & $\mathrm{C}$ & $55-81$ & Abrupt, smooth & Dark grayish brown & Loamy sand & Single grain \\
\hline & $\mathrm{R}$ & $81+$ & Indurated bedrock & - & - & - \\
\hline \multirow{5}{*}{$\begin{array}{l}\text { Sigadi } \\
\text { (P8) }\end{array}$} & Ap & $0-16$ & Clear, smooth & Dark yellowish brown & Sandy loam & Disturbed \\
\hline & $\mathrm{A} 2$ & $16-38$ & Clear, smooth & Yellowish brown & Sandy loam & Disturbed \\
\hline & A3 & $38-67$ & Gradual, smooth & Yellowish brown & Sandy loam & Single grain \\
\hline & $\mathrm{C}$ & $67-105$ & Abrupt, smooth & Yellowish brown & Loamy sand & Single grain \\
\hline & $\mathrm{R}$ & $105+$ & Indurated bedrock & - & - & - \\
\hline \multirow{6}{*}{$\begin{array}{l}\text { Gularjhala } \\
\text { (P9) }\end{array}$} & Ap & $0-19$ & Clear smooth & Dark brown & Sandy loam & Disturbed \\
\hline & Bw1 & $19-36$ & Gradual smooth & Dark yellowish brown & Sandy loam & $\mathrm{m} 1 \mathrm{sbk}$ \\
\hline & Bw2 & $36-61$ & Gradual smooth & Dark yellowish brown & Sandy loam & $\mathrm{m} 1 \mathrm{sbk}$ \\
\hline & Bw3 & $61-92$ & Clear smooth & Dark yellowish brown & Sandy loam & m1sbk \\
\hline & $\mathrm{C}$ & $92-115$ & Abrupt smooth & Dark yellowish brown & Sandy loam & f1sbk \\
\hline & $\mathrm{C}_{\mathrm{R}}$ & $115+$ & $\begin{array}{l}\text { Unconsolidated } \\
\text { bedrock }\end{array}$ & - & - & - \\
\hline \multirow{7}{*}{$\begin{array}{l}\text { Chourikhal } \\
\text { (P10) }\end{array}$} & Ap & $0-15$ & Gradual, smooth & Brown & Sandy clay loam & Disturbed \\
\hline & $\mathrm{A} 2$ & $15-34$ & Clear, smooth & Brown & Sandy clay loam & Disturbed \\
\hline & Bw1 & $34-50$ & Clear, smooth & Brown & Sandy clay loam & f1sbk \\
\hline & Bw2 & $50-77$ & Gradual, smooth & Dark yellowish brown & Sandy clay loam & m1sbk \\
\hline & Bw3 & $77-104$ & Gradual, smooth & Dark yellowish brown & Sandy clay loam & m2sbk \\
\hline & Bw4 & 104-134 & Gradual, smooth & Dark yellowish brown & Sandy clay loam & m2sbk \\
\hline & Bw5 & $134-158$ & Clear, smooth & Dark yellowish brown & Sandy clay loam & $\mathrm{m} 2 \mathrm{sbk}$ \\
\hline
\end{tabular}

* m 1 sbk: Medium, weak, sub angular blocky; f 1 sbk: fine weak sub angular blocky; m 2 sbk: medium, moderate, sub angular blocky. 


\begin{tabular}{|l|l|l|}
\hline \multicolumn{3}{|l|}{ Table.3 Taxonomy of soils } \\
\hline Soils & Description & Taxonomy \\
\hline Phoolchatti (P1) & $\begin{array}{l}\text { Very shallow, excessively drained, gravelly loamy sand soils of yellowish } \\
\text { brown colour developed on mica schist }\end{array}$ & Lithic Udorthents \\
\hline Umrda (P2) & $\begin{array}{l}\text { Shallow, excessively drained, gravelly sandy loam soils of yellowish } \\
\text { brown colour developed on sandstone }\end{array}$ & Lithic Udorthents \\
\hline Jollu (P3) & $\begin{array}{l}\text { Moderately shallow, excessively drained, loamy sand soils of yellowish } \\
\text { brown colour, developed on mica schist }\end{array}$ & TypicUdipsamments \\
\hline Mundai (P4) & $\begin{array}{l}\text { Moderately deep, excessively drained, gravelly loamy sand soils of grayish } \\
\text { brown colour developed on mica schist }\end{array}$ & TypicUdorthents \\
\hline Kainur (P5) & $\begin{array}{l}\text { Very shallow, excessively drained, gravelly loamy sand soils of grayish } \\
\text { brown colour developed on mica schist }\end{array}$ & Lithic Udorthents \\
\hline Maun (P6) & $\begin{array}{l}\text { Shallow, excessively drained, gravelly sandy loam soils of brown colour } \\
\text { developed on sandstone }\end{array}$ & Lithic Udorthents \\
\hline Bhandeli (P7) & $\begin{array}{l}\text { Moderately deep, excessively drained, loamy sand soils of grayish brown } \\
\text { colour, developed on mica schist }\end{array}$ & TypicUdipsamments \\
\hline Sigadi (P8) & $\begin{array}{l}\text { Deep, somewhat excessively drained, sandy loam soils of yellowish brown } \\
\text { colour developed on sandstone }\end{array}$ & TypicUdorthents \\
\hline Gularjhala (P9) & $\begin{array}{l}\text { Deep, well drained, sandy loam soils of dark yellowish brown colour, } \\
\text { medium weak sub angular blocky structure, developed on } \\
\text { colluvium/alluvium }\end{array}$ & TypicDystrudepts \\
\hline Chourikhal (P10) & $\begin{array}{l}\text { Very deep, well drained, sandy clay loam soils of brown to dark yellowish } \\
\text { brown colour, medium moderate sub angular blocky structure, developed } \\
\text { on alluvium/colluvium DystricEutrudepts }\end{array}$ \\
\hline
\end{tabular}

Fig.1 Study area, Purvi Nayyar River watershed, Pauri Garhwal

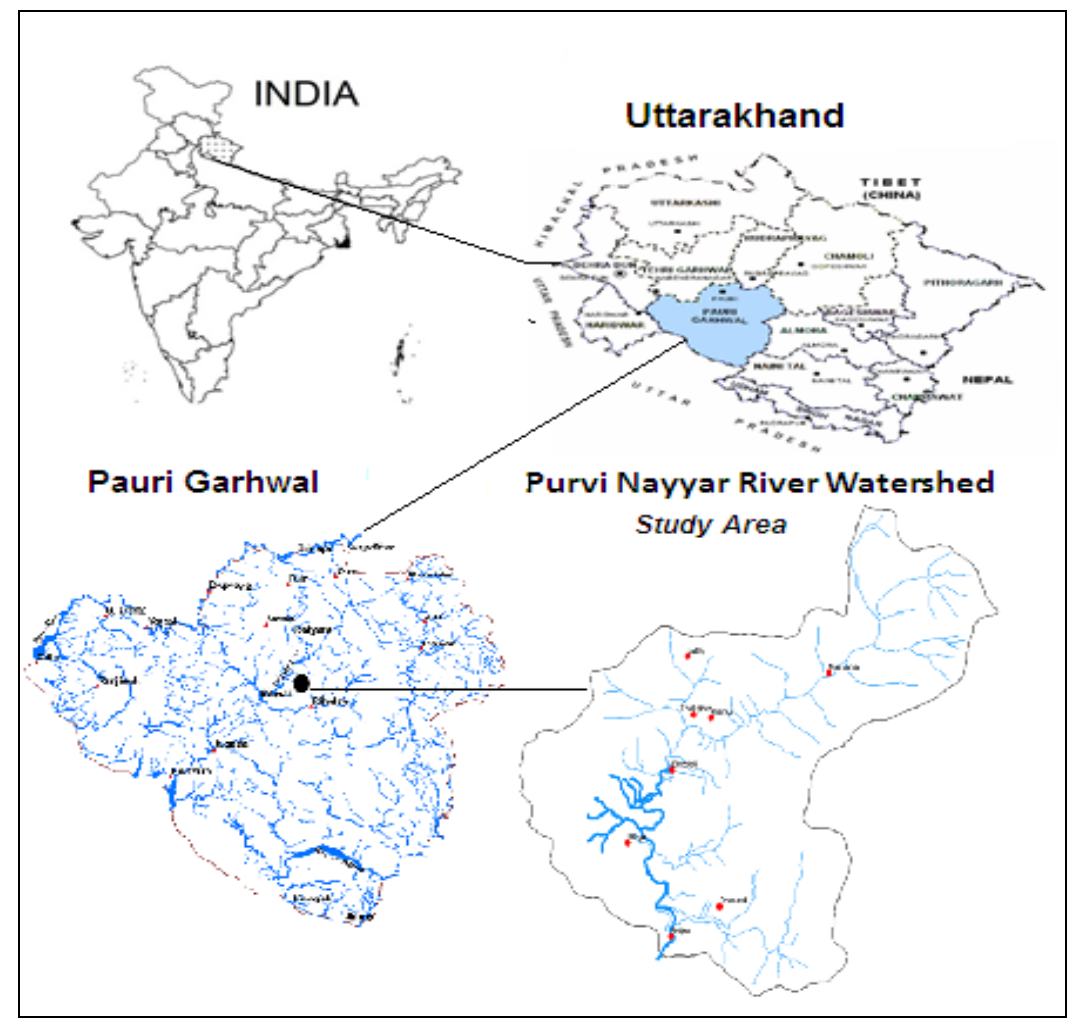


Fig.2 Physiographic land unit (PLU) map of Purvi Nayyar river watershed

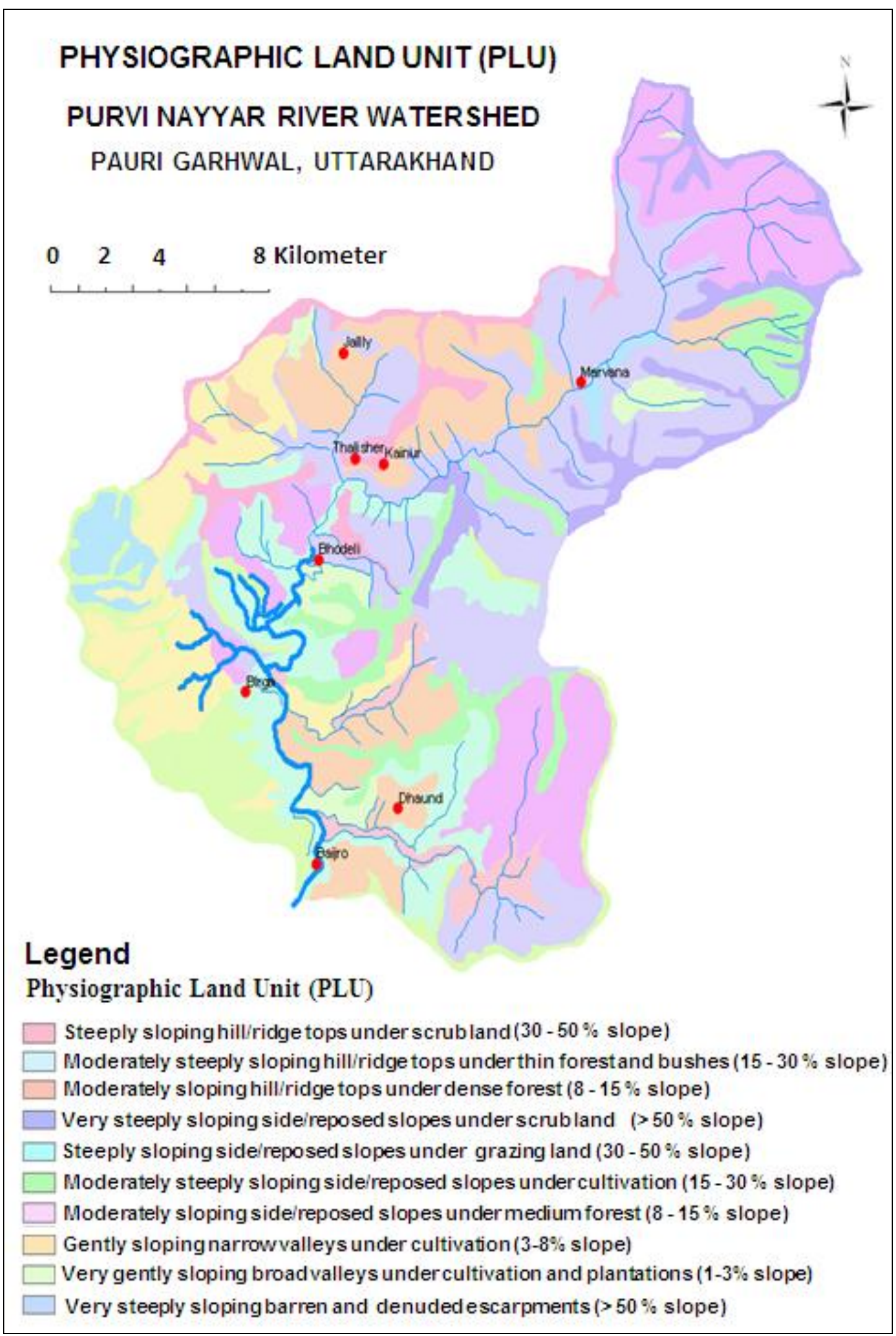


Fig.3 Soil map of Purvi Nayyar river watershed

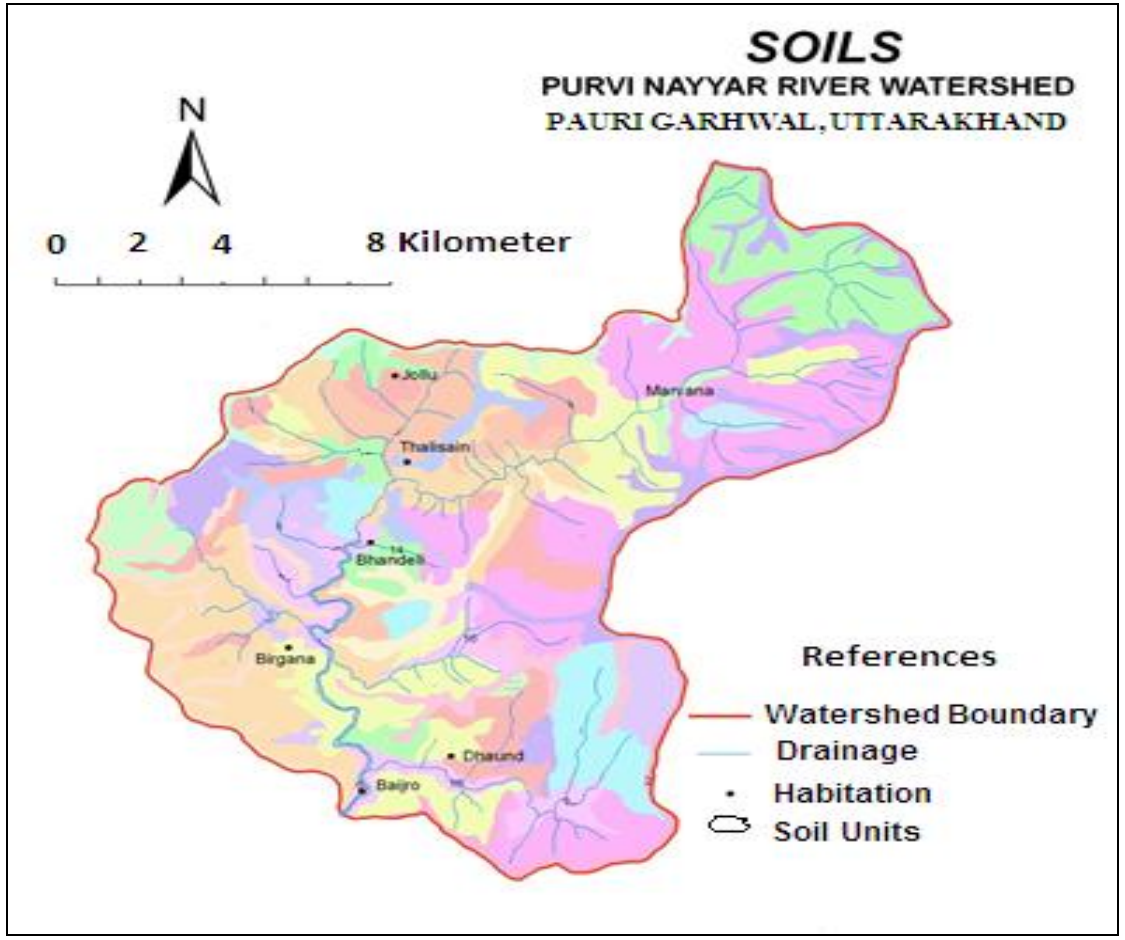

Fig.4 Soil reaction $(\mathrm{pH})$ map of Purvi Nayyar river watershed

SOIL REACTION (pH)

PURVI NAYYAR RIVER WATERSHED

PAURI GARHWAL, UTTARAKHAND

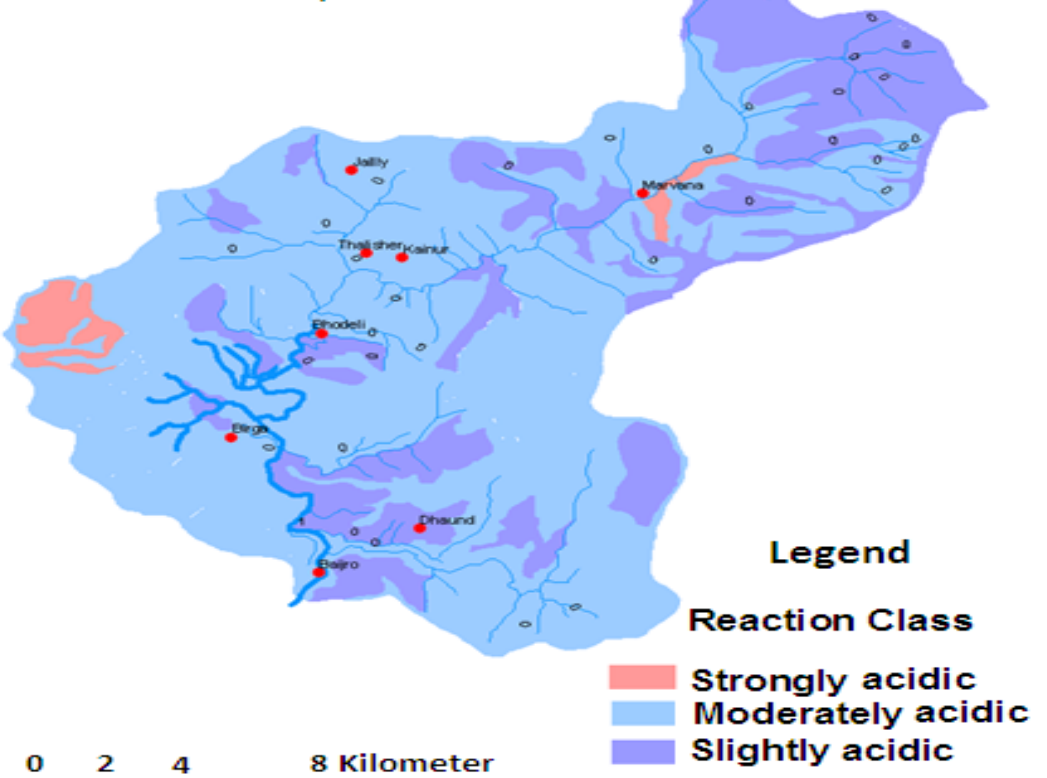

pH range

Strongly acidic

$5.1-5.5$

Slightly acidic

$5.6-6.0$

$6.1-6.5$ 
Fig.5 Electrical conductivity (EC) map of Purvi Nayyar river watershed

\section{ELECTRICAL CONDUCTIVITY (EC) PURVI NAYYAR RIVER WATERSHED \\ PAURI GARHWAL, UTTARAKHAND}

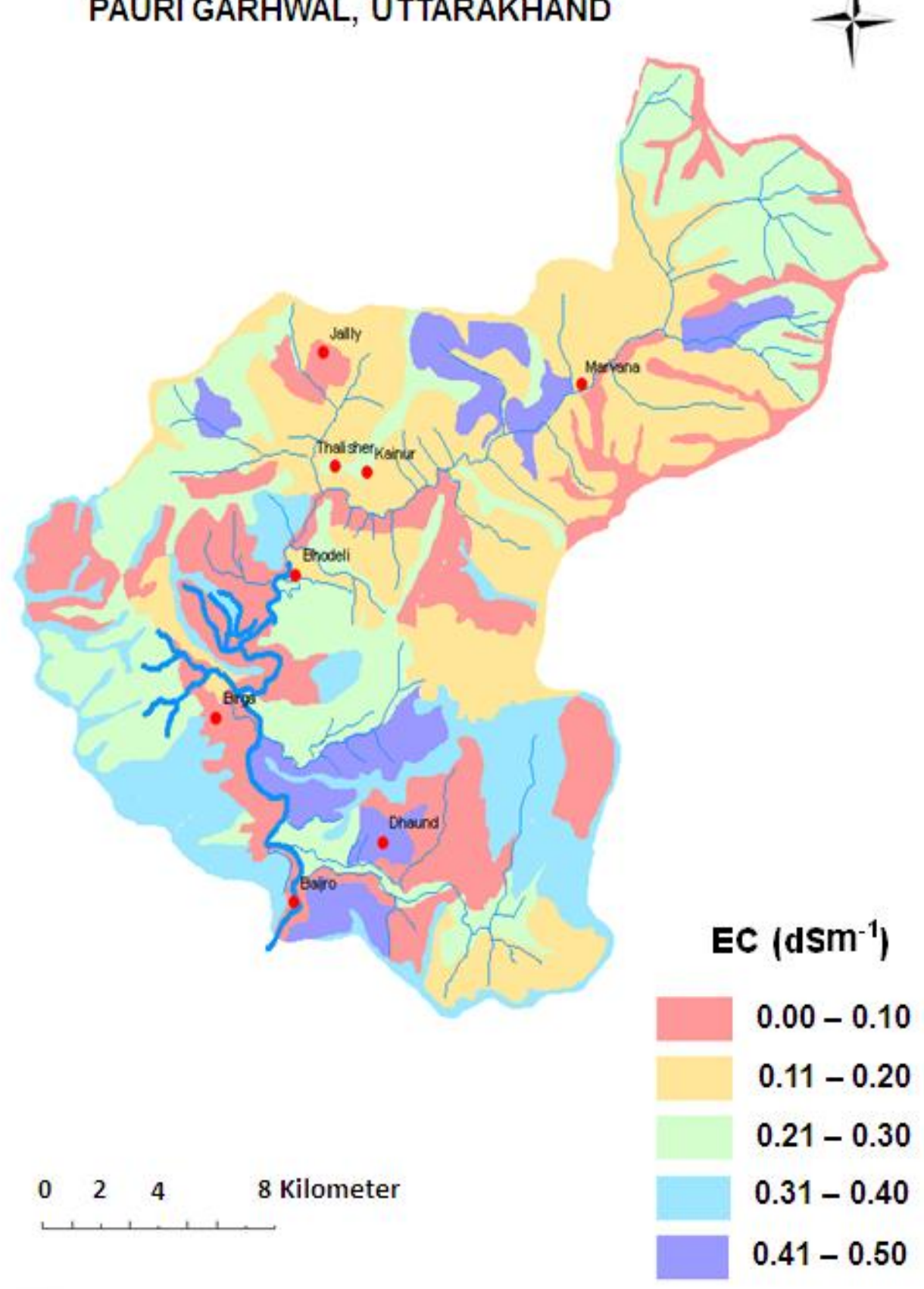


Fig.6 Clay content map of Purvi Nayyar river watershed

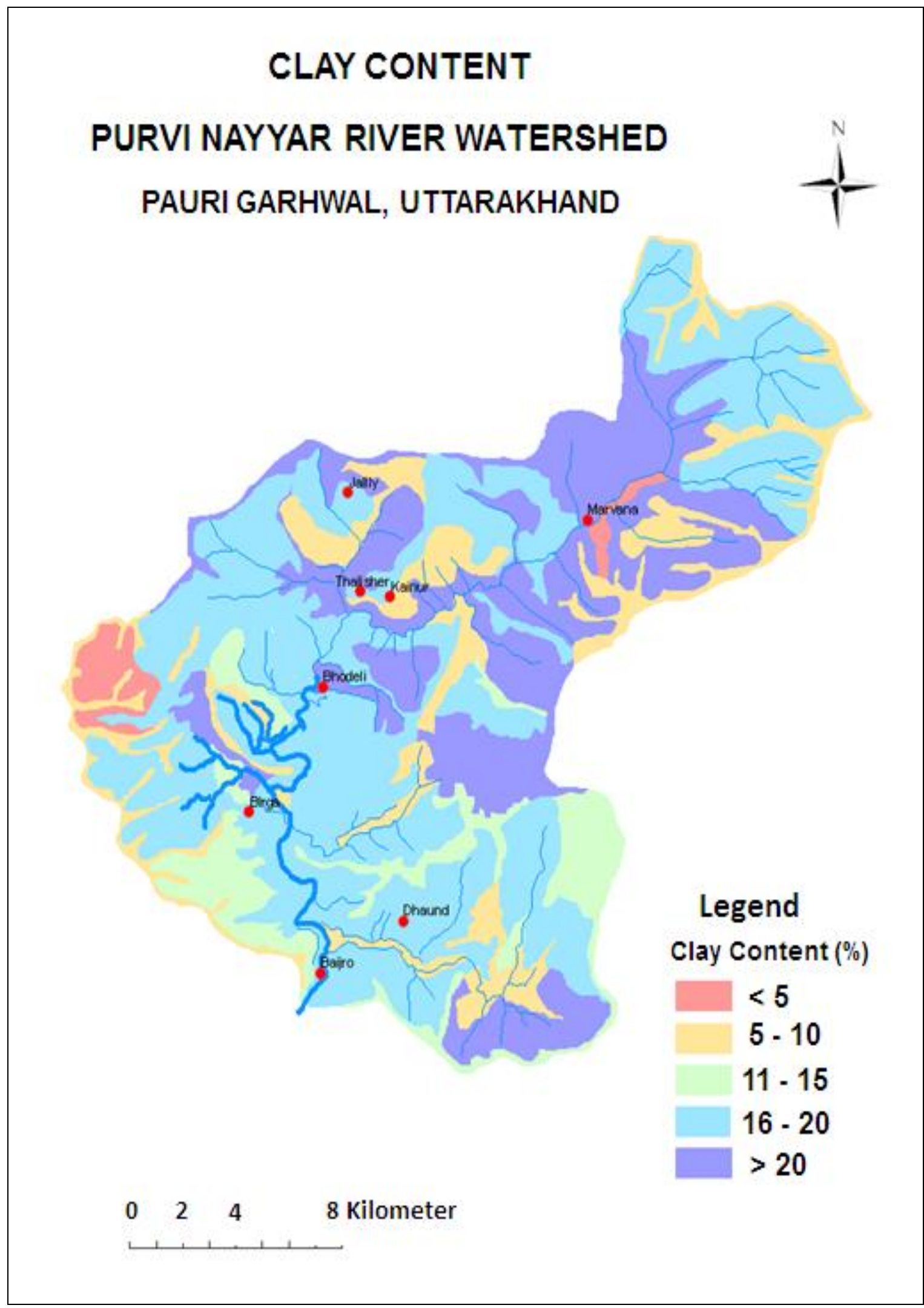


Fig.7 Cationexchange capacity (CEC) map of Purvi Nayyar river watershed

\section{CATION EXCHANGE CAPACITY (CEC)}

PURVINAYYAR RIVER WATERSHED

PAURI GARHWAL, UTTARAKHAND
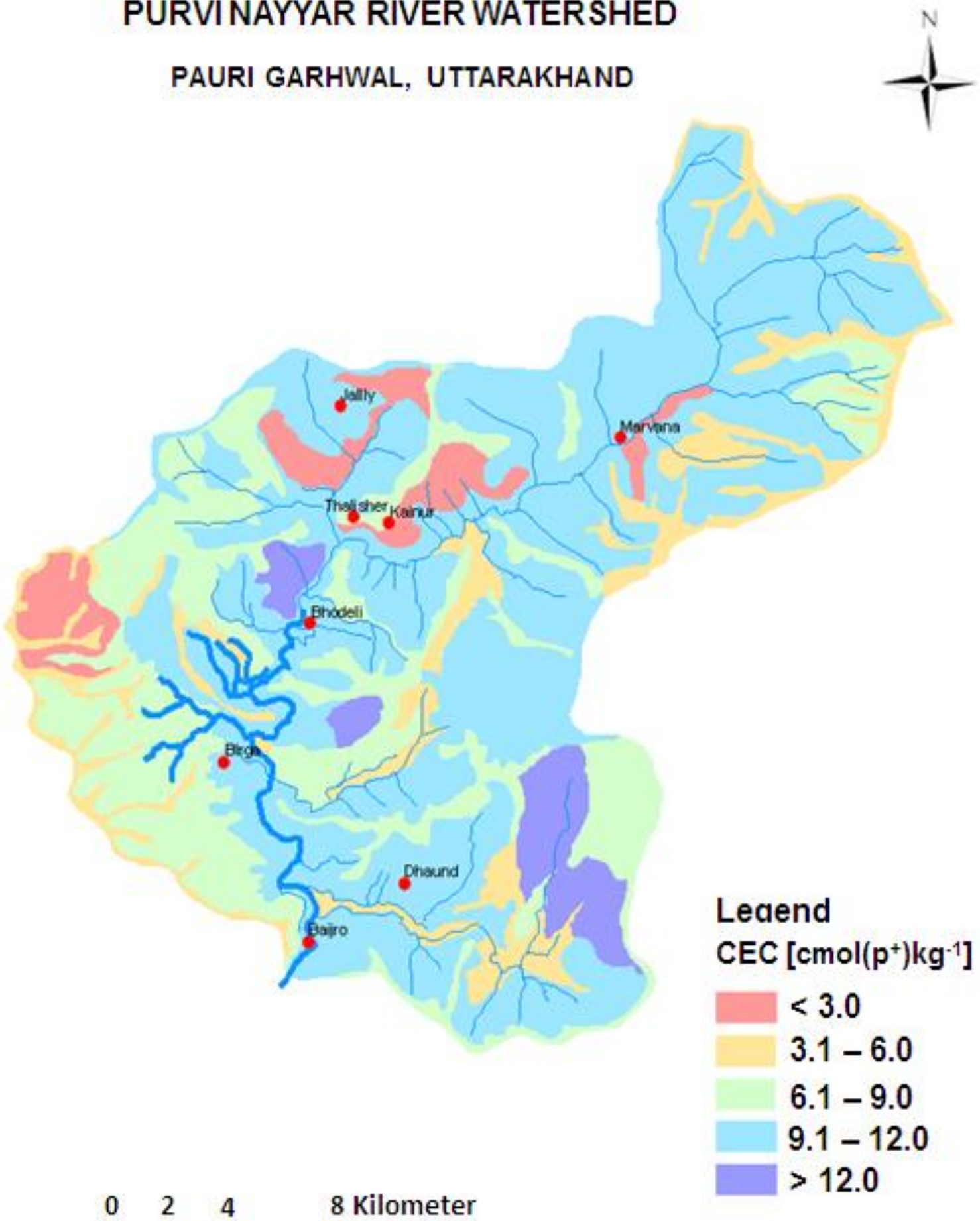
Fig.8 Soil erosion and deforestation in study area

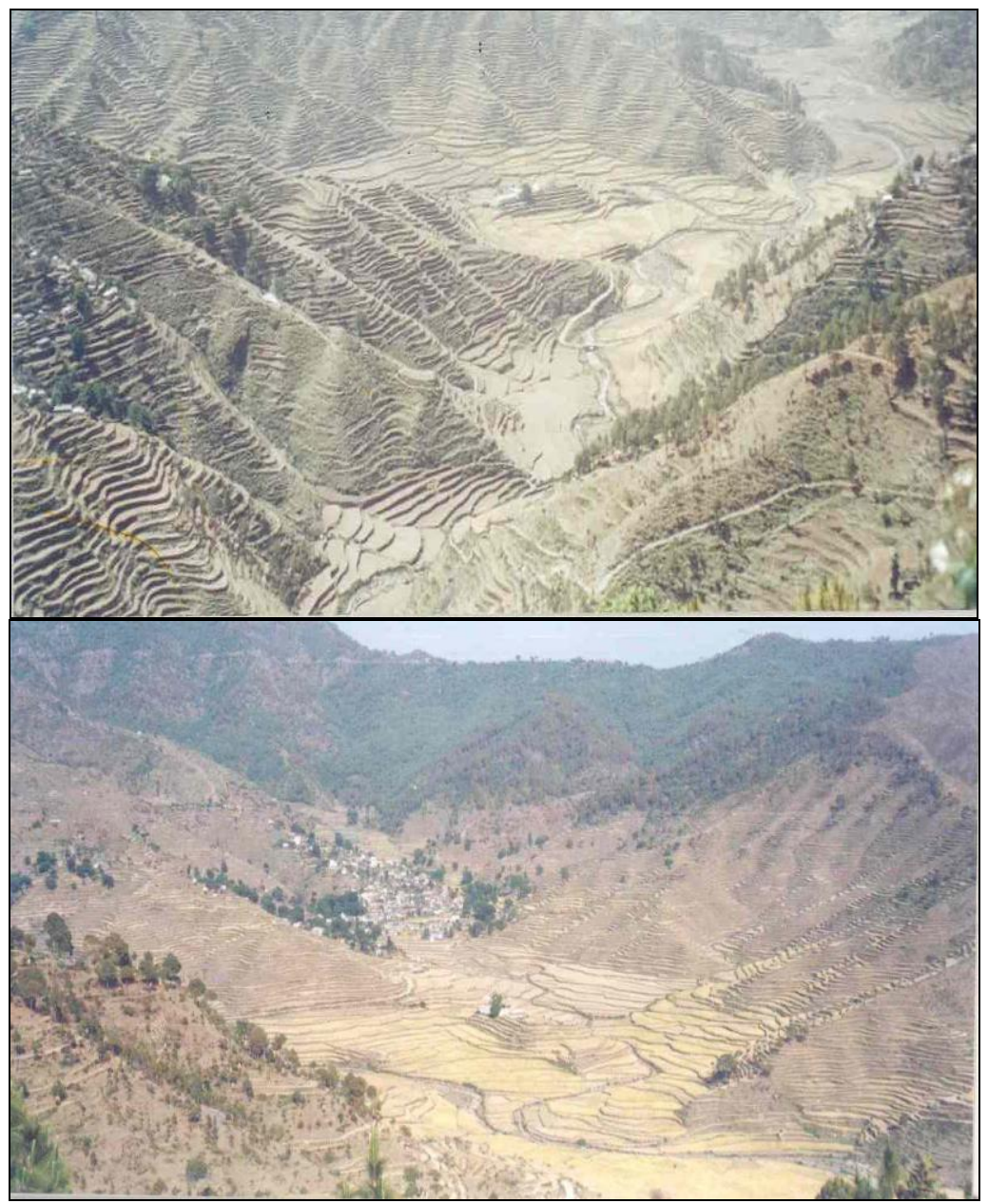

They are the most developed soils in the study area having cambic diagnostic sub-surface horizon and belong to Inceptisols having fine loamy family textural class and base saturation more than $60 \%$ and no free carbonates throughout the profile. Hence they are classified as very deep, mixed, thermic, fine loamy, Dystric Eutrudepts.

Thus, from the data it is revealed that major soils of the watershed belong to Entisols followed by Inceptisols. Among the Entisols, Lithic (very shallow to shallow in depth i.e. less than $50 \mathrm{~cm}$ ) Udorthents cover more area than Typic Udorthents. Among the Inceptisols, Typic Dystrudepts occupy major area than Dystric Eutrudepts.

\section{Soil erosion and its remedial measures}

The study area is highly susceptible to various kinds of degradational constraints viz., severe to very severe soil erosion, deforestation, landslides, etc. (Fig. 8). The major causes of land degradation are sloppy landscape, human interventions (deforestation and overgrazing), high intense and low frequent rainfall and inappropriate agricultural activities. It leads to poor soil fertility, low productivity and poor soil quality besides environmental hazards (Blum, 1997). The present agriculture system in this region is under threat due to these degradational features and continuous exploitation of the natural resources. Thus, agricultural sustainability and food security 
have become a major concern in this hilly region. Hence, it is required to adopt the proper soil and water conservation measures to minimize the risk of natural resource degradation for enhancing crop productivity.

Proper engineering measures as well as soil and water conservation practices should be undertaken to protect the soils from further deteriorations. The conservation practices to be implemented are include contour trenching/staggered trenching/contour furrows, close spacing erosion resistant crops, inter-cropping or strip cropping. Soil management practices such as land leveling are required to improve organic matter and soil structure. Adoption of silvi-pastoral or horti-pastoral systems with emphasis on cover management, vegetation or plant cover, pasture and forest development, terraces and grass water ways be done to reduce the soil erosion. Development of proper engineering structures may be implemented for disposal of excess rain water to water harvesting bodies' viz., ponds, reservoirs, etc. to minimise the degradations caused by water erosion. Besides, afforestation may be encouraged on priority bases to arrest soil erosion (Nagdev et al., 2017). The areas of shallow soils which are not suitable for agriculture and tree growth may be used for pasture development (Singh et al., 1990; Sidhu et al., 2010). The crops may be cultivated using good agronomic practices like contour farming, mulching, inter-cropping with legumes, application of high yielding seeds, manures, fertilizers, etc.

Thus, the study revealed that by using remote sensing and GIS techniques physiographic boundaries could be delineated in details and the information extracted from FCC could be extrapolated to inaccessible areas with similar image characteristics. Identification of landforms and soils as well as study of agrienvironmental features are pre-requisites for conservation of natural resources and watershed development. Soil is the most indispensable natural resource and hence, it should be managed carefully for sustainable agricultural production and livelihood security of the people of this hilly region.

\section{Acknowledgement}

Authors are thankful to the Director, ICAR, NBSS\&LUP, Nagpur, Maharashtra, India for providing necessary facilities and support for conducting the present research work.

\section{References}

Bhattacharya, T., Sarkar, Dipak and Pal, D.K. (Ed.), 2009.Soil Survey Manual. NBSS \& LUP, Publication No. 146: 1-400.

Black, C.A. (Ed.), 1965. Methods of Soil Analysis; Part I. American Society Madison, Wisconsis, USA.

Blum, W.E. H., 1997. Basic concepts: degradation, resilience, and rehabilitation. In Methods for assessment of soil degradation. Lalv R, Blum WEH, Valentine C and Stewart B.A (Ed.), CRC press, New York.1-16.

Divakar, B.L., Bhagat, K.N., Tewari, J.C. and Mehta, N.S. 1989. Soil fertility status of horticultural areas in Nainital district of U.P. hills (hilly region). Progressive Horticulture, 21: 95-99.

Dwivedi, R.S., 2001. Soil resource mapping; a remote sensing perspective. Remote Sensing Reviews, 20: 89-122.

Ghosh, B.N., and Singh, R.D. 2002.Suitability of soil test methods for available phosphorus and its critical levels for maize in acid soils of Uttaranchal hills. Journal of the Indian Society of Soil Science, 50: 132-134.

Gorai T., Ahmed, N., Mahapatra, S.K., Datta, S.C., Singh, R.D. and Sharma, R.K. 2013.Effect of topography and vegetation on soil development in Kumaon hills of North Western Himalayas. Journal of Soil and water Conservation, 12 (4): 269-276.

Jackson, M.L., 1966. Soil Chemicals Analysis. Prentice Hall of India Pvt. Ltd; New Delhi.

Kumar, S., and Sharma, A.K. 1987. Numerical 
classification of some hill soils of Uttar Pradesh. Journal of the Indian Society of Soil Science.35: 465-473.

Mahapatra, S.K., Jagat, Ram, Singh, S.P., Dhankar, R.P. 2005. Soil Resource Inventory of Warm Humid Kumaon Himalayas for Sustainable Land Use. Journal of the Indian Society of Soil Science, 53 (3): 390-393.

Mishra, B.B., and Ghosh, S.K. 1995. Characteriztion of soils derived from mica rich parent materials in two toposequences. Journal of the Indian Society of Soil Science, 43 (1), 92-98.

Nagdev, Ritu, Mahapatra, S.K., Yadav, R.P. and Singh, S.K. 2017. Land capability classification and management needs in Aravalli fringes of southern Haryana for sustainable land use planning. Journal of Soil and Water Conservation, 16(2): 117-125.

Pai, C.W., Wang, M.K. and Chiu, C.Y. 2007. Clay mineralogical characterization of a toposequence of perhumid subalpine forest soils in north eastern Taiwan. Geoderma, 138: 177-184.

Rawat, G.S., Ramana, Murthy, J., Suman, Kumar, Murthy, R.J. and Kumar, S. 1994. Characteristics and classification of soils of Shivaliks in relation to land use. Advances in Forestry Research in India, 10: 45-53.

Reddy, G.P.O., Maji, A.K., Nagaraju, M.S.S. Thaylan, S. and Rama Murthy, V. 2008. Ecological evaluation of land resources and land use system for sustainable development at watershed level in different agro-ecological zones of Vidarbha region, Maharashtra using Remote Sensing and GIS techniques. Project Report, NBSS\&LUP, Nagpur, pp. 270.

Sahu, Nisha, Singh, S.K., Obi Reddy, G.P., Nirmal, Kumar, Nagaraju, M.S.S. and Srivastava, Rajeev, 2016. Large scale soil resource mapping using IRS P6 LISS IV and Cartosat-1 DEM in Basaltic Terrain of Central India. Journal of Indian Society of Remote Sensing, 44 (5): 811-819.

Sawhney, J. S., Deka, B., Sharma, B.D. and Sidhu, P.S. 1996. Magnitude of soil variability in morphological and other properties across different landscape in the Siwalik Hills of Punjab. Journal Indian Society of Soil Science, 44: 465-469.

Sehgal, J.L., Saxena, R.K. and Vadivelu, S. 1987. Field Mannual; Soil Resource Mapping of Different States. Bull. 13, NBSS \& LUP, Nagpur.

Sharma, V.A.K., Krishnan, P. and Budhial, S.L. 1987. Laboratory Methods; Soil Resource, Mapping of Different States in India. Bull. 14, NBSS\&LUP, Nagpur.

Sidhu, G.S., Yadav, R.P., Singh, S.P., Sharma, J.P., Aggarwal, R.K., Tiwari, A.K., Gajbhiye, K.S., Sarkar, Dipak and Sharda, V.N. 2010.Soil erosion in Himachal Pradesh, NBSS Publ. 132, NBSS \& LUP, Nagpur, India, pp. 53.

Singh, Gurmel, Venkataramanan, C., Sastry, G. and Joshi, B.P. 1990. Manual of soil and water conservation practices. Oxford and IBH Publishing Company Private Limited, New Delhi.

Singh, R.D., and Bhatnagar, V.K. 1997. Differences in soil and leaf litter nutrient status under Pinus, Cedrus and Quercus. Indian Journal of Forestry, 20: 147-149.

Soil Survey Staff, 2014.Keys to Soil Taxonomy, NRCS, Washington D.C., USA.

Srivastava, R., and Saxena, R.K., 2004. Techniques of large scale soil mapping in basaltic Tarrain using satellite remote sensing data. International Journal of Remote Sensing, 25(4): 679-688.

\section{How to cite this article:}

Ritu Nagdev, S.K. Mahapatra, R.P. Yadav and Singh, S.K. 2017. Delineation and Characterization of Purvi Nayyar River Watershed in Mid-Himalayan Region of India Using Remote Sensing and GIS Techniques. Int.J.Curr.Microbiol.App.Sci. 6(9): 2047-2062. doi: https://doi.org/10.20546/ijcmas.2017.609.252 